\title{
Analysis of possibilities of using biomass from cherry and morello cherry stones for energy purposes
}

\author{
Andrzej Bryśs ${ }^{1, *}$, Joanna Zielińska ${ }^{1}$, Szymon Głowacki ${ }^{1}$, Weronika Tulej ${ }^{1}$, and Joanna Bryś ${ }^{2}$ \\ ${ }^{1}$ Warsaw University of Life Sciences, Faculty of Production Engineering, Nowoursynowska st. 164, \\ 02-787 Warsaw, Poland \\ ${ }^{2}$ Warsaw University of Life Sciences, Faculty of Food Sciences, Nowoursynowska st. 159 C, 02-776 \\ Warsaw, Poland
}

\begin{abstract}
Growing demand for energy and care about natural environment is the motivation to find alternative sources of energy. One of them is biomass from cherry and morello cherry stones, which is food processing industry waste. Stones have fairly good physical properties regarding material for combustion. Cherry and morello cherry crop in Poland is at the level of 200 thousand tons yearly, and processing them generates a considerable amount of waste that consists of stones, which may be used for energy purposes. In the work, the initial water content (u), curves of combustion in different temperatures, percentage ash content, heat of combustion and percentage share of stone in the whole fruit were determined.
\end{abstract}

Keywords: biomass, cherry and morello cherry stones, drying, heat of combustion, ash

\section{Introduction}

Demand for heat, electrical and mechanical energy in Poland and worldwide has been increasing together with civilizational development. In the $20^{\text {th }}$ century, the conventional and most convenient fossil fuel was natural gas, coal and crude oil. These raw materials have been used for many years. However, with civilizational progress, more environmentally friendly energy solutions have started to be sought. Fossil fuels combustion has a negative impact on the quality of the air. Toxic substances, harmful dust, and other by-products of fossil fuels combustion have adverse effect on the natural environment and the climate. Moreover, fossil fuel deposits are exhausting. Decreasing reserves of such fuels as well as environmental pollution are a stimulus for seeking alternative solutions related to generation of energy [1]. Seeking new methods to generate energy contributes to increased interest in renewable resources of energy. In literature, five types of renewable resources of energy are distinguished:

- solar energy,

- wind energy,

*Corresponding author: andrzej_brys@sggw.pl 
- geothermal energy,

- waste and renewable energy resources, e.g. biomass,

- river, sea waves and tide energy [2].

Biomass is one of the biggest renewable resources of energy [3], and its use for energy purposes generates less pollution to the natural environment and the climate. Biomass is either natural waste or energy plants, which may be used for the production of energy. It is one of the cheapest and the most promising forms of renewable resources of energy. Easy access and relatively low cost of production of energy may result in the increased use of biomass, which may be a breakthrough in power industry. It is estimated that only approx. $8 \%$ of the biomass available is used worldwide. The highest use of biomass is in developing countries - approx. 36\%. In industrialized and highly-developed countries, use of biomass is as low as 3-5\% [4].

The crucial factors that have impact on use of biomass include:

- relatively low cost of biomass, which is usually waste left over from production,

- possibility to use surplus animal and agricultural-derived products as a source of biomass,

- development of new direction of production as well as development of local markets and rural regions, which results in creating new workplaces in farming industry in order to grow and cultivate plants used for energy purposes,

- combustion of biomass limits emission of toxins and substances harmful to people and natural environment,

- possibility of energy security and smaller exploitation of fossil fuel deposits [5].

Production, or more often, obtaining biomass does not require special conditions. In the countries, where farming and industry are highly developed, there is no problem in obtaining waste materials that may be used as biomass. Smaller availability of biomass may occur in countries with small forestation and barren soils, which could limit production of biomass.

One type of biomass is cherry and morello cherry waste left over from processing. The part of cherry and morello cherry that may be used to obtain biomass is stone. Renewable energy is generated from combustion of stones of these fruits.

Cherries and morello cherries are produced in Europe and outside it. One of the biggest global producers of morello cherries, according to the estimates (statistical data are not fully confirmed) is Russia. Ukraine may become a leading country in morello cherry production in the nearest future. The number of morello cherry trees grown in Ukraine has been rising sharply since 2014 [6]. Leading producers of morello cherries are Turkey, the United States of America, Hungary and Iran. Hungary and Serbia produce approx. 75-80 thousand tons of morello cherries. Morello production in Poland is twofold higher. However, these countries should not be underestimated as this fruit producers, since they have great fruit farming potential.

Cherries, like morello cherries grow in many countries, and in 2017, global production of this fruit amounted to over 2 million tons. In 2017, the highest crop of cherries, amounting to nearly 500 thousand tons, was harvested in Turkey. Like with cherries, the leading producer of morello cherries was the USA, which harvested as much as 430 thousand tons of cherries. It is estimated that China (330 thousand tons in 2017), whose production of cherries increased by $9.1 \%$ compared with the previous year, may become a leading producer of cherries. Cherry and morello cherry crops vary considerably worldwide, and changing market as well as climatic changes, which have impact on cultivation, will force leading fruit producers on global markets adjust to these changing conditions. Recently, fruit farming has been developing dynamically, which results in higher crops in such countries as China. The analysis of statistical data for average crops in 
the years 1993- 2014 shows that the United States and Turkey were not leaders in morello cherry production at the beginning of this period [7].

Poland is one of leading producers of fruit in Europe. In the years 2000-2015, Poland had the highest crops of apples, morello cherries, currant and raspberries. Cultivation and production of fruits in the above period was a key factor that had impact on the structure of the whole farming industry. Poland was a leading producer of morello cherry in the years 2000-2015 in the European Union, with the crops at the level of 140 200 thousand tons, and relatively high variation in crops in successive years (fig. 1).

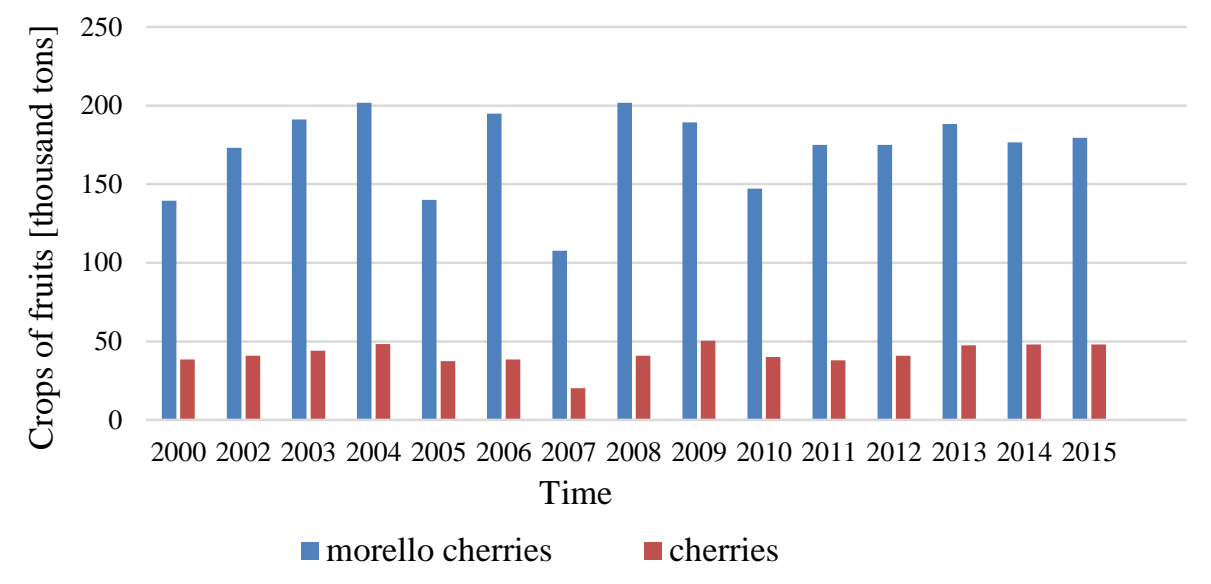

Fig. 1. Production of morello cherries and cherries in Poland in the years 2000-2015 [8]

In 2007, the crop of fruit was significantly lower, and amounted to 105 thousand tons. The share of cherry, with the annual estimated crop of 50 thousand tons in the years 2000-2015, was significantly lower. Differences between crops of cherries were significant in the period of 15 years. Also, in 2007 the crop of cherries was the lowest, at the level of 20 thousand tons. Due to relatively small production, cherries were sold on domestic market, with small surplus being exported [8].

Despite variations in crops and seasonality, cherry and morello cherry stones seem good materials for the production of energy, all the more so because they are waste product left over after processing not only in Poland but also worldwide. Therefore, it is desirable to investigate basic physical properties of this biomass for energy purposes.

\section{Material and methods}

Three varieties of fruits, most frequently cultivated in Poland, were used for the experiments, i.e.:

- light cherry „Vega” (Lat. Prunus avium Vega),

- dark cherry „Burlat” (Lat. Prunus avium Burlat),

- morello cherry (Lat. Prunus cerasus L.).

Biomass (stones) was obtained from cherries and the following experiments were performed:

- determination of a percentage content of stone mass to the mass of the whole fruit,

- determination of initial water content (u) in stones by drying and weighing method, 
- determination of changes of water content during drying in the convective dryer at the temperatures of $30-35^{\circ} \mathrm{C}, 50^{\circ} \mathrm{C}$ and $80^{\circ} \mathrm{C}$,

- determination of ash content by combustion of stones in ceramic crucibles at the temperature of $600^{\circ} \mathrm{C}$ in the muffle furnace,

- determination of heat of combustion in pressure calorimetric bomb in oxygen atmosphere.

All the experiments were performed in triplicate, and the result is the average from the three measurements.

\section{Results and discussion}

Morello cherry and cherry stones are a waste product in food processing industry. High percentage content of stones in the whole fruit mass is a loss for production plants. It is therefore worth considering this waste product as a source of biomass for energy purposes. Morello cherry has a considerably high content of stone in the whole mass of the fruit, amounting to nearly $10 \%$, with relatively low initial water content amounting to $0.67 \mathrm{~kg}$ $\mathrm{H}_{2} \mathrm{O} / \mathrm{kg}$ d.s. Stones of the two examined cherry varieties have higher initial water content (u) and a smaller share in the whole mass of the fruit, which is presented in table 1 . The comparison of these properties to the properties of e.g. nut shells (pistachio, hazelnut, walnut, peanut), which have initial water contents (u) of $0.002,0.158,0.124$ and $0.050 \mathrm{~kg}$ $\mathrm{H}_{2} \mathrm{O} / \mathrm{kg}$ d.s., respectively [9], shows that stones of these fruits are worse material for energy purposes.

Table 1. Percentage content of stone in the fruit and the initial water content in the stone.

\begin{tabular}{lcc}
\hline Stone of fruit variety & $\begin{array}{c}\text { Stone content in the whole fruit } \\
\text { mass } \\
\%\end{array}$ & $\begin{array}{c}\text { Initial water content in } \\
\text { the stone } \\
\mathrm{kg} \mathrm{H} \mathrm{O} / \mathrm{kg} \mathrm{d.s.}\end{array}$ \\
\hline Light cherry „Vega” & 6.00 & 0.96 \\
Dark cherry „Burlat” & 6.53 & 1.36 \\
Morello cherry & 9.98 & 0.67 \\
\hline
\end{tabular}

Due to high content of water $(\mathrm{u})$, stones were dried at three different temperatures $30-35^{\circ} \mathrm{C}$, $50^{\circ} \mathrm{C}$ and $80^{\circ} \mathrm{C}$. The content of water decreased most sharply at the temperature of $80^{\circ} \mathrm{C}$, and the slowest decrease in water content was at the temperature of $30-35^{\circ} \mathrm{C}$ in all cases, which is presented in fig. 2. It may be observed that, irrespective of the initial water content (u), stones of all varieties of cherries were completely dried after 6 hours of drying at the temperature of $80^{\circ} \mathrm{C}$. Morello cherry and light cherry „Vega” stones drying time at the temperature of $30-35^{\circ} \mathrm{C}$ was equal approx. 50-60 hours, and for dark cherry „Burlat” stones the time exceeded 60 hours), while at the temperature of $50^{\circ} \mathrm{C}$ the drying time shortened to approx. 30 hours (fig. 3). Drying time of stones is thrice as long as drying biomass from grass (dried in similar conditions at the temperature of $80^{\circ} \mathrm{C}[10]$. 


\section{ICORES 2019}

a)

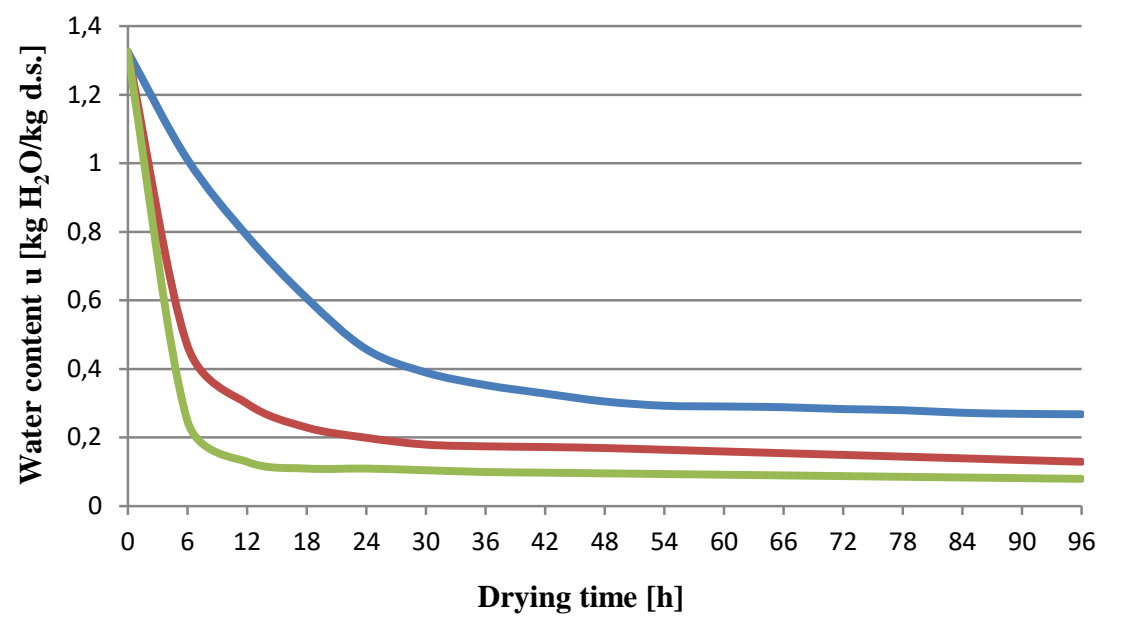

Drying curve at the temperature of $30^{\circ} \mathrm{C} \longrightarrow$ Drying curve at the temperature of $50^{\circ} \mathrm{C}$ Drying curve at the temperature of $80^{\circ} \mathrm{C}$

b)

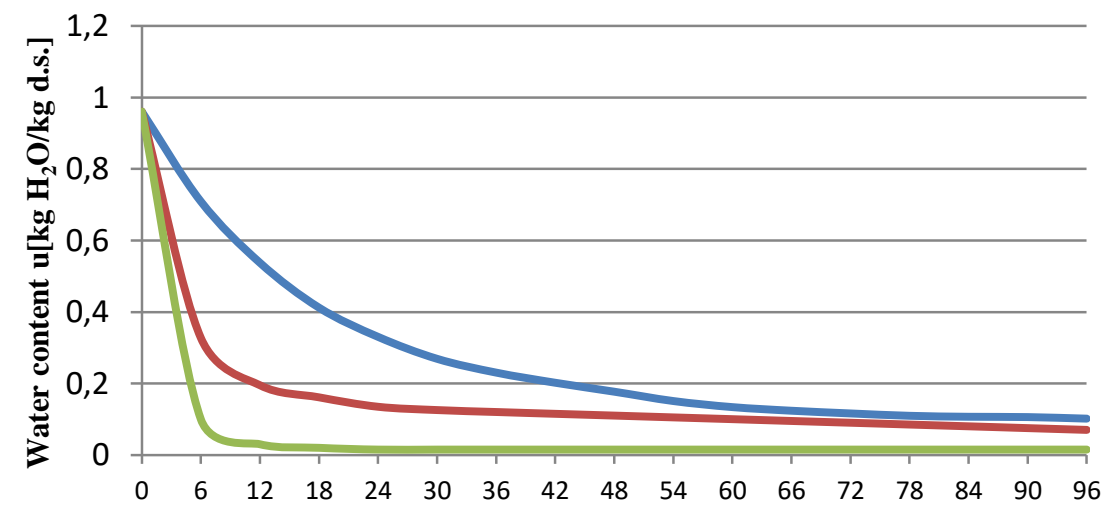

Drying time $[\mathbf{h}]$

Drying curve at the temperature of $30^{\circ} \mathrm{C} \longrightarrow$ Drying curve at the temperature of $50^{\circ} \mathrm{C}$ Drying curve at the temperature of $80^{\circ} \mathrm{C}$ 
c)

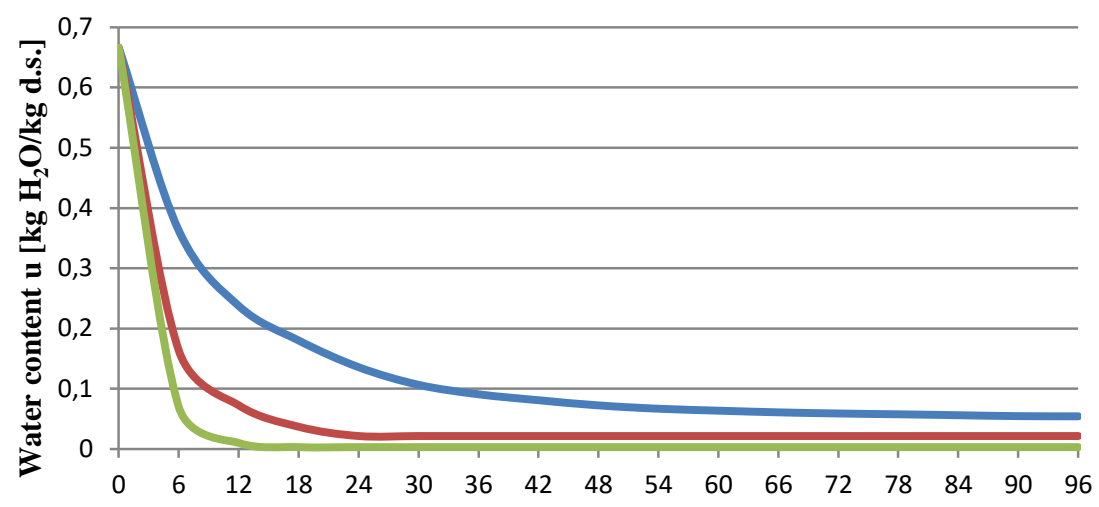

Drying time $[\mathrm{h}]$

Drying curve at the temperature of $30^{\circ} \mathrm{C} \longrightarrow$ Drying curve at the temperature of $50^{\circ} \mathrm{C}$ Drying curve at the temperature of $80^{\circ} \mathrm{C}$

Fig. 2. Drying curves of stones of: a) dark cherry „Burlat”; b) light cherry „Vega”; c) morello cherry, at the temperature of $30-35^{\circ} \mathrm{C}, 50^{\circ} \mathrm{C}$ and $80^{\circ} \mathrm{C}$.

a)

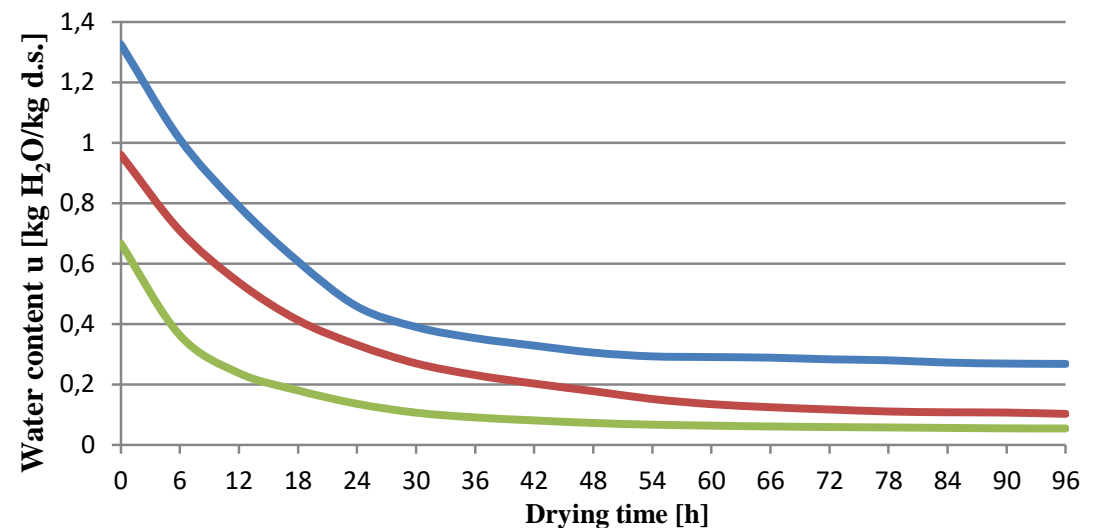

Drying time [h]

Drying curve of dark cherry „Burlat”

Drying curve of morello cherry 
b)

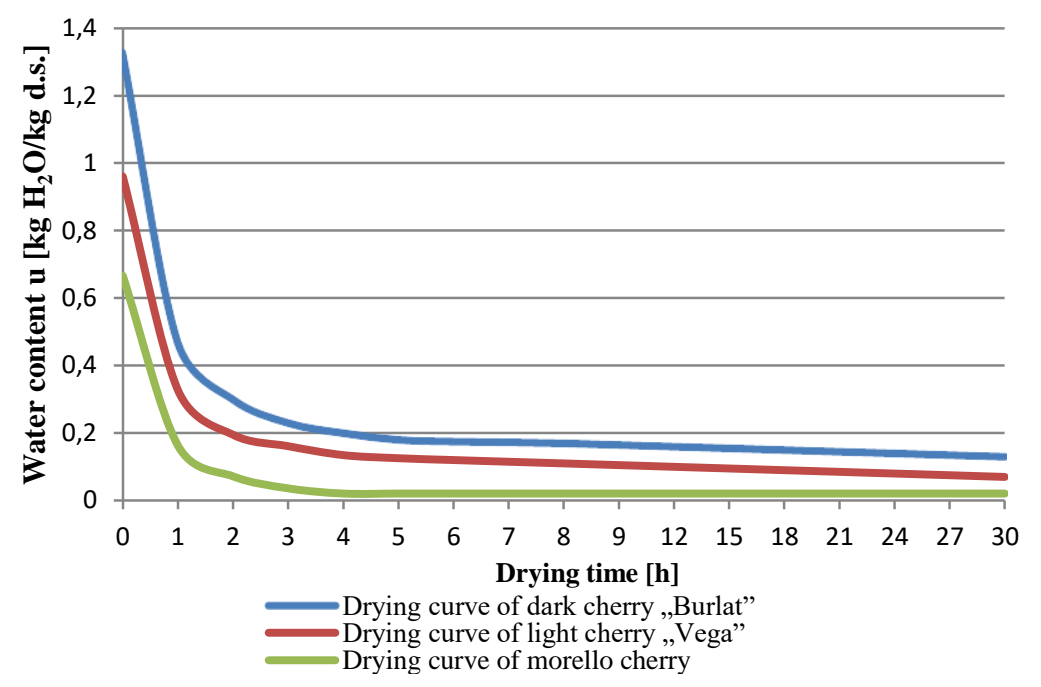

c)

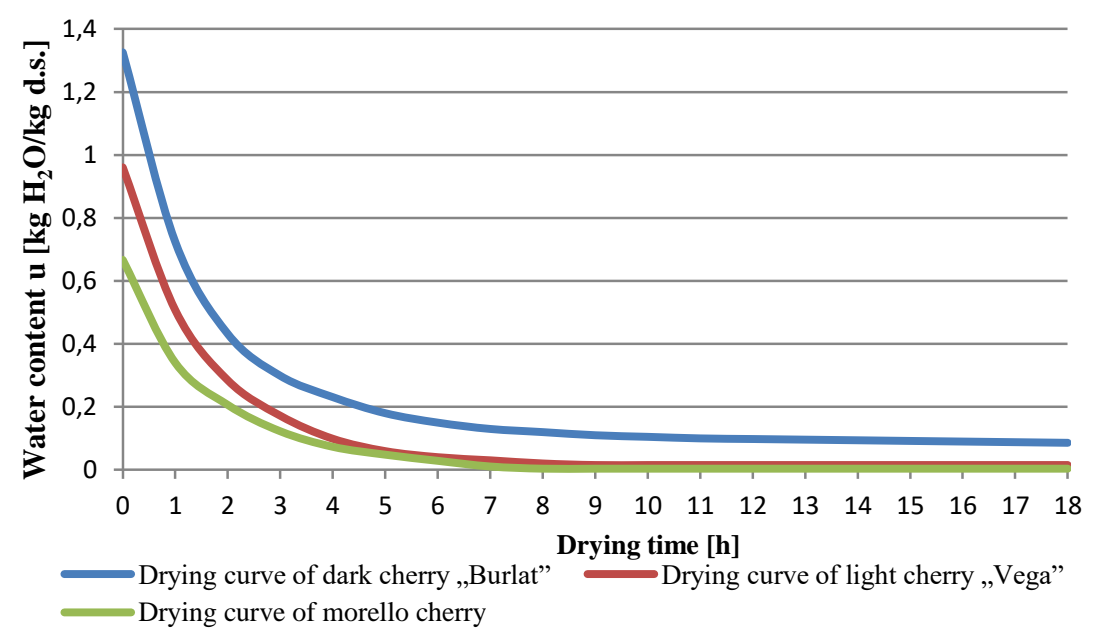

Fig. 3. Drying curves of stones of fruit varieties at different temperatures: a) $30-35^{\circ} \mathrm{C}$; b) $50^{\circ} \mathrm{C}$, c)

$80^{\circ} \mathrm{C}$.

Drying process in high temperatures is related to considerable financial outlay for generation of heat required for drying, which was reduced to 6 hours. Drying stones in low temperatures $30-35^{\circ} \mathrm{C}$ using solar dryers is an interesting alternative, however, long drying time, which may exceed 60 hours, requires consideration.

Ash content in all the examined samples of stones is very low and does not exceed $1 \%$ for all the examined stones. Compared with biomass from grass, for which ash content may amount to as much as $8 \%$ [10] it is a very good result. Heat of combustion is the highest for morello cherry stone and amounts to nearly $22 \mathrm{~kJ} / \mathrm{g}$ (table 2 ). 
Table 2. Ash content and heat of combustion of stones.

\begin{tabular}{lcc}
\hline Stone of fruit variety & $\begin{array}{c}\text { Ash content } \\
\%\end{array}$ & $\begin{array}{c}\text { Heat of } \\
\text { combustion kJ/g }\end{array}$ \\
\hline Light cherry „Vega” & 0.71 & 21.162 \\
Dark cherry „Burlat” & 0.26 & 20.257 \\
Morello cherry & 0.25 & 21.974 \\
\hline
\end{tabular}

Based on the analysis of the obtained results, it may be concluded that the best biomass of the examined types of biomass is biomass from morello cherry stones as it is grown in largest quantities in Poland, has the lowest initial water content and ash content, as well as the highest heat of combustion.

\section{Summary and results}

Using biomass from morello cherry and cherry stones for energy purposes has numerous benefits as it is environmentally friendly, does not contribute to air quality deterioration and does not have a negative impact on climate. Combusting waste morello cherry and cherry stones, with simultaneous generation of energy in this process also helps manage waste products, which would otherwise be difficult to utilize. Additionally, dried stones may easily be stored, which allows to use them when need arises.

Biomass from morello cherry and cherry is relatively non-exhaustible material, which may be obtained as long as the fruits are cultivated and harvested, which is opposite to fossil fuels, which are no longer available when the deposits have exhausted.

Biomass from morello cherries and cherries is characterized by very good parameters, has low ash content (below 1\%) and relatively high value of heat of combustion (above $20 \mathrm{~kJ} / \mathrm{g}$ ).

Drying time of stones to water content below $0.12 \mathrm{~kg} \mathrm{H}_{2} \mathrm{O} / \mathrm{kg}$ d.s. at the temperature of $80^{\circ} \mathrm{C}$ was equal approx. 6 hours for all types of stones, while drying at the temperature of $30-35^{\circ} \mathrm{C}$ took over 60 hours for stones of dark cherry of „Burlat” variety.

A serious limitation in obtaining biomass from morello cherry and cherry stones is inevitably fruit seasonality. Biomass from morello cherry and cherry stones is usually produced during and immediately after harvest.

\section{References}

1. A. Grzybek, Wieś Jutra. 1, 7-9 (2008)

2. Z. Kęsek, Czasopismo techniczne. R. 104, z. 3-A, 107-113 (2007)

3. G. Bernedes, M. Hoogwijk, R. Van den Broek. Biomass Bioen. 25, 1-28 (2003)

4. W. Lewandowski, Proekologiczne źródta energii odnawialnej (WNT, Warszawa 2012)

5. B. Sawicka, B. Krochmal-Marczak. Zeszyty Naukowo-Dydaktyczne PWSZ Krosno, Produkcja roślinna. 33, 79-99 (2014)

6. P. Brzozowski, K. Zmarlicki. Instytut ogrodnictwa. Raport 2017

7. S. Kierczyńska. Problemy Rolnictwa Światowego. 17, 177-186 (2017)

8. Główny Urząd Statystyczny.Zbiory owoców w latach 2000-2013 (Warszawa, 2015)

9. A. Bryś, M. Sokalska, S. Głowacki, W. Tulej, J. Bryś, M. Sojak, Renewable Energy

Sources: Engineering, Technology, Innovation. (to be published 2019) 
10. A. Bryś, J. Bryś, S. Głowacki, W. Tulej, P. Zajkowski, M. Sojak, Renewable Energy Sources: Engineering, Technology, Innovation. $443-449$ (2018). 